\title{
Pilot-Scale Synthesis of TV-45070
}

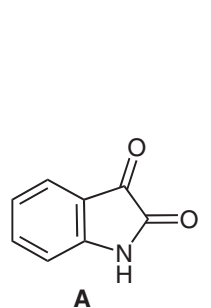

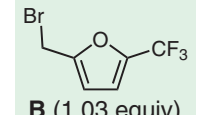

B (1.03 equiv)

$\mathrm{K}_{2} \mathrm{CO}_{3}$ (1.6 equiv) DMF, $48^{\circ} \mathrm{C}, 2 \mathrm{~h}$

add $\mathbf{C}$ (1.1 equiv) $30{ }^{\circ} \mathrm{C}, 3 \mathrm{~h}$ $94 \%$ (61.2 mol scale)<smiles>Cc1ccc2c(c1)OCCO2</smiles><smiles>O=C1N(Cc2ccc(C(F)(F)F)o2)c2ccccc2C1(O)c1cc2c(cc1O)OCO2</smiles>

D
1. $\mathrm{Et}_{3} \mathrm{SiH}$ (1.3 equiv) TFA (6.0 equiv) $\mathrm{CH}_{2} \mathrm{Cl}_{2}, 0-25^{\circ} \mathrm{C}, 2 \mathrm{~h}$ $91 \%$ (43.1 mol scale)

2. TBDMSCI (1.3 equiv) $\mathrm{Et}_{3} \mathrm{~N}$ (2.2 equiv) THF, $25^{\circ} \mathrm{C}, 20 \mathrm{~h}$ $88 \%$ (38.8 mol scale) brown solid

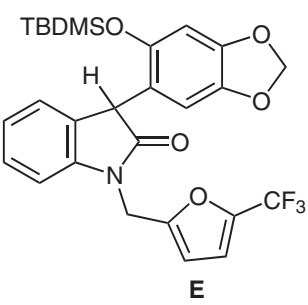

mp not reported

Gategory

Synthesis of Natural

Products and

Potential Drugs

\section{Key words}

TV-45070

asymmetric aldol reaction

organocatalysis

\section{thiourea}

deoxygenation

spirocyclization<smiles>CCCCOc1cc2c(cc1[C@@]1(CO)C(=O)N(Cc3ccc(C(F)(F)F)o3)c3ccccc31)OCO2</smiles>

(S) $\mathbf{G}$

$99.2 \%$ ee

$\mathrm{HBr}(0.13$ equiv)

$\mathrm{MeCN}-\mathrm{H}_{2} \mathrm{O}, 37^{\circ} \mathrm{C}, 6 \mathrm{~h}$

$19 \mathrm{~mol}$ scale

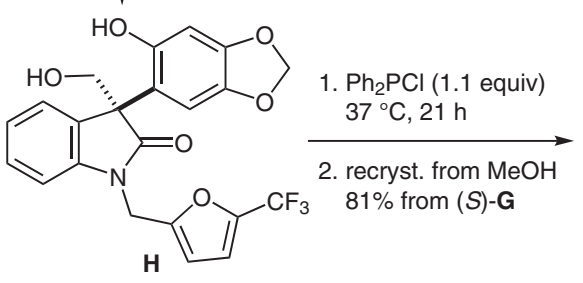
$58 \%$ from $\mathbf{F}$ suspend solid in $\mathrm{MeOH}-\mathrm{AcOH}(24: 1), 50^{\circ} \mathrm{C}, 1 \mathrm{~h}$; cool to $20^{\circ} \mathrm{C}$ and stir slurry for $20 \mathrm{~h}$ filter off racemate; add $\mathrm{H}_{2} \mathrm{O}$ to filtrate

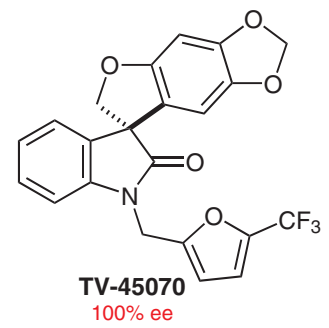<smiles>CCCCOc1cc2c(cc1[C@@]1(CO)C(=O)N(Cc3ccc(C(F)(F)F)o3)c3ccccc31)OCO2</smiles>

F (0.011 equiv) $(\mathrm{HCHO})_{n}$ (1.0 equiv) $\mathrm{HCHO}$ ( 1.1 equiv)

$\mathrm{H}_{2} \mathrm{O}$-heptane

$25^{\circ} \mathrm{C}, 47 \mathrm{~h}$ $96 \%$ (36.1 mol scale)

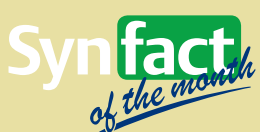

Significance: TV-45070 is an antagonist of the $\mathrm{Na}_{\mathrm{v}} 1.7$ sodium ion channel protein that is of interest for the treatment of chronic pain associated with shingles. The key step in the synthesis depicted is the asymmetric aldol reaction of the enolate derived from $\mathbf{E}$ with a mixture of solid paraformaldehyde and aqueous formaldehyde using only $1.1 \mathrm{~mol} \%$ of thiourea catalyst $\mathbf{F}$ to give adduct $\mathbf{G}$ in $96 \%$ yield and $70.5 \%$ ee. This solid product was heated in $\mathrm{MeOH}$ at $50{ }^{\circ} \mathrm{C}$ and cooled to $20^{\circ} \mathrm{C}$ whereupon the near racemic product $\mathbf{G}(5 \%$ ee) precipitated. Addition of water to the supernatent afforded (S)-H in 99\% ee and 58\% yield.
Comment: Attempts to synthesize chloro or mesylate intermediates from diol $\mathbf{H}$ using conventional reagents were unsuccessful due to the congested neopentyl center. Diethyl chlorophosphate, dichlorophenyl phosphine, and diethylchlorophosphite did not provide sufficient conversion or a good impurity profile. However, chlorodiphenylphosphine completely consumed $\mathbf{H}$ when heated to $37^{\circ} \mathrm{C}$ and provided the spirocycle in $81 \%$ yield. For a preceding asymmetric synthesis of TV-45070, see: S. Sun et al. US 9,487,535, 2016. For a synthesis of catalyst $\mathbf{F}$, see: $Y$. Wang et al. Org. Process Res. Dev. 2017, 21, 408. 